\title{
RENAL AMYLOID
}

\section{A REPORT ON ELEVEN CASES PROVEN BY RENAL BIOPSY}

BY

\author{
R. H. HEPTINSTALl AND A. M. JOEKES \\ St. Mary's Hospital, London \\ and \\ Institute of Urology, London
}

Amyloid deposition in the kidneys and other organs represents an intriguing anomaly. The whole problem, with a discussion of so-called primary and secondary amyloidosis, has been fully reviewed in recent years (Symmers, 1956).

Amyloidosis occurs secondarily to a variety of chronic diseases, in particular those with chronic suppuration, but also in association with such conditions as rheumatoid arthritis and multiple myelomatosis. Since the introduction of many potent antimicrobial agents, such chronic infections are becoming uncommon, and a higher proportion of cases of secondary amyloidosis will be found in association with other conditions. The association of amyloid with rheumatoid arthritis is the most striking. Fingerman and Andrus (1943) found some amyloid deposits in thirteen of 61 autopsies on patients with rheumatoid, and Teilum and Lindahl

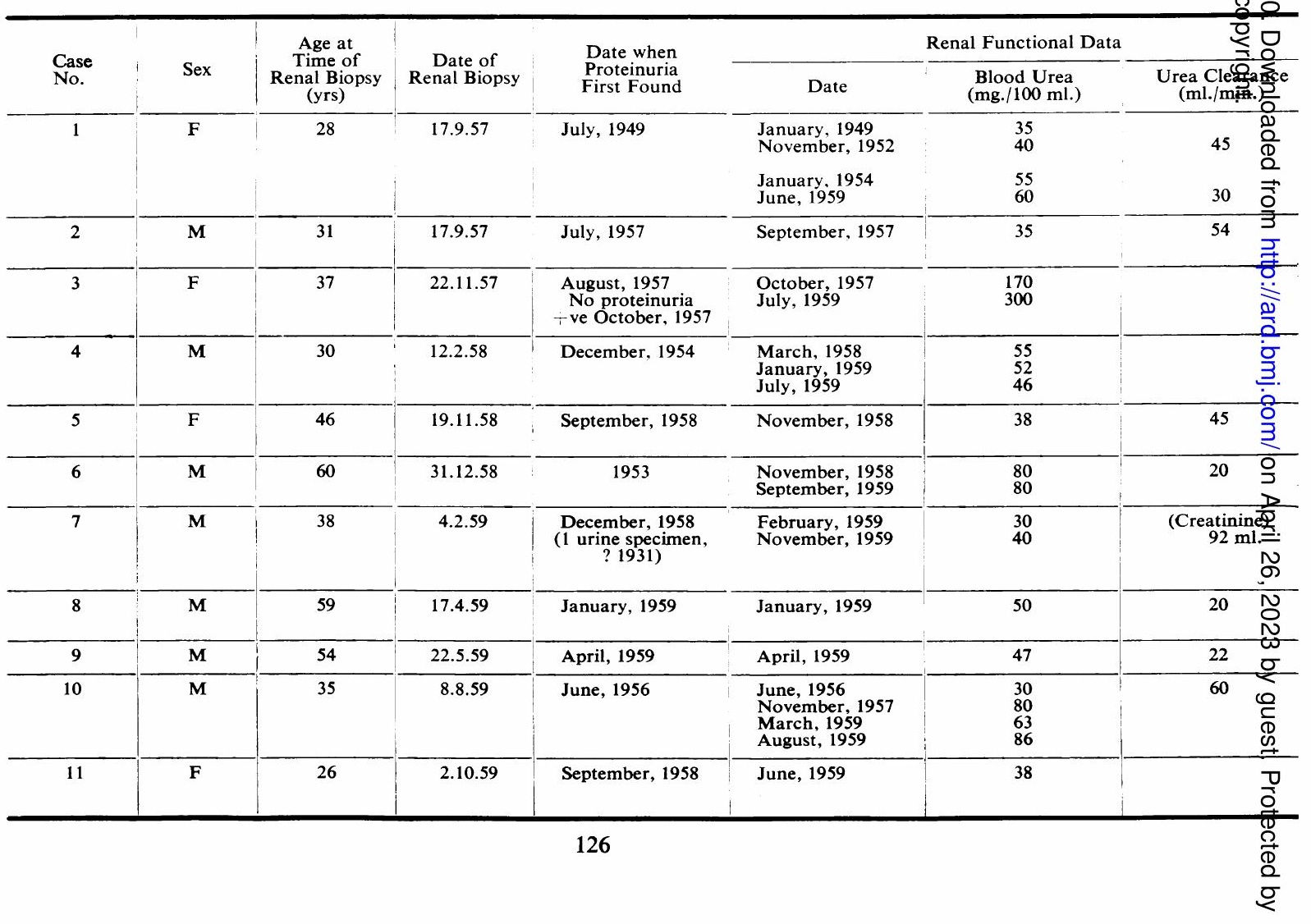


(1954) claimed an incidence of 60 per cent. in autopsy material. Fearnley and Lackner (1955) made a clinical diagnosis of amyloid in eight of 183 patients with rheumatoid arthritis seen during a single one-year period.

In 220 successful renal biopsies, eleven cases of amyloid infiltration have been found. This surprisingly high incidence has led us to document these patients. Apart from questioning the generally held belief that amyloid disease is now a rarity, some interesting problems are posed by the long interval in some cases between establishing the presence of amyloid infiltration of the kidneys and any possible causative underlying disease.

Brief clinical histories are given below. Table I sets out some of the salient features of the eleven cases; there is obviously no proof of the relationship of any underlying disease to the amyloid deposition.

\section{Case Reports}

Case 1, a female aged 28. - In 1939 (at age 11) an operation was performed for osteomyelitis of the left hip. In 1940 there was a recurrence of the abscess in the same region and she was put in plaster; the left hip was fully ankylosed by December, 1941. In 1942 the sinus in the left groin broke down. In 1943 the head of the right humerus was explored and the sequestrum removed. Between December, 1944, and May, 1946, she had four recurrences of abscess formation in relation to the left hip. In December, 1947, the left hip was drained and she was treated with penicillin. In January, 1949, two-thirds of the ala of the left ilium which contained two sequestra were removed. In July, 1949, proteinuria was found at a routine medical examination. Chronic nephritis was diagnosed, hypertension slowly developed, and progressive impairment of renal function occurred. The hypertension became severe with diastolic levels up to $150 \mathrm{~mm}$. $\mathrm{Hg}$ in 1954, when occasional small haemorrhages were present in the fundi.

After the episode of severe hypertension in 1954, energetic hypotensive therapy was instituted; the blood pressure has been well controlled and renal function has remained approximately static. She leads a full normal life and gave birth to a normal live child in 1957 (by Caesarean section), the year in which the renal biopsy was performed. There has been no evidence of active osteomyelitis since 1949 . She was last seen in December, 1959, when proteinuria was still present.

\begin{tabular}{|c|c|c|c|c|c|}
\hline $\begin{array}{l}\text { Interval between Last } \\
\text { Evidence of Activity } \\
\text { of Possible Underlying } \\
\text { Lesion and Renal Biopsy }\end{array}$ & $\begin{array}{l}\text { Highest } \\
\text { B.P. } \\
\text { (mm. Hg) }\end{array}$ & $\begin{array}{c}\text { Heaviest } \\
\text { Proteinuria } \\
(\mathrm{g} . / 24 \mathrm{hrs})\end{array}$ & $\begin{array}{c}\underset{\text { Maximum }}{\text { Oedema }} \\
(0 \text { to }++++)\end{array}$ & $\begin{array}{c}\text { Lowest } \\
\text { Plasma } \\
\text { Albumin } \\
\text { (g./100 ml.) }\end{array}$ & $\begin{array}{c}\text { Highest } \\
\text { Serum } \\
\text { Cholesterol } \\
\text { (mg. } / 100 \mathrm{ml} .)\end{array}$ \\
\hline $\begin{array}{c}8 \text { years } \\
\text { (Osteomyelitis) }\end{array}$ & $240 / 150$ & $3 \cdot 0$ & 0 & $3 \cdot 5$ & 123 \\
\hline $\begin{array}{l}13 \text { years } \\
\text { (Osteomyelitis) }\end{array}$ & $150 / 102$ & $1 \cdot 0$ & 0 & $3 \cdot 2$ & 184 \\
\hline $\begin{array}{l}5 \text { months } \\
\text { (Osteomyelitis) }\end{array}$ & $230 / 130$ & $8 \cdot 0$ & 0 & $3 \cdot 3$ & 280 \\
\hline $\begin{array}{c}3 \text { years } \\
\text { (Pulmonary tuberculosis) }\end{array}$ & $180 / 100$ & $12 \cdot 0$ & 0 & $4 \cdot 0$ & 212 \\
\hline $\begin{array}{c}\text { Still active } \\
\text { (Rheumatoid arthritis) }\end{array}$ & $130 / 80$ & $4 \cdot 0$ & 0 & & 211 \\
\hline $\begin{array}{c}40 \text { years } \\
\text { (Osteomyelitis) }\end{array}$ & $150 / 90$ & $20 \cdot 0$ & + & $2 \cdot 0$ & 125 \\
\hline $\begin{array}{c}25 \text { years } \\
\text { (Osteomyelitis) } \\
1 \text { year } \\
\text { (Ulcerative colitis) }\end{array}$ & $130 / 80$ & $15 \cdot 0$ & +++ & $1 \cdot 2$ & 160 \\
\hline $\begin{array}{c}\text { Still active } \\
\text { (Purulent bronchiectasis) }\end{array}$ & $100 / 65$ & $14 \cdot 0$ & 0 & $3 \cdot 0$ & 330 \\
\hline None & $160 / 110$ & $7 \cdot 5$ & $\div$ & $2 \cdot 5$ & 252 \\
\hline $\begin{array}{c}10 \text { years } \\
\text { (Pulmonary and genital tuberculosis) }\end{array}$ & $180 / 120$ & $20 \cdot 0$ & ++ & $2 \cdot 4$ & 283 \\
\hline $\begin{array}{c}10 \text { years } \\
\text { (Bronchiectasis) }\end{array}$ & $140 / 75$ & $5 \cdot 3$ & 0 & $3 \cdot 1$ & - \\
\hline
\end{tabular}


Case 2, a male aged 31.-In 1929 (at age 3) he fractured the right arm, and this was followed by infection and metastatic osteomyelitis in the left orbit and cheek, right ring finger, right elbow, and cervical spine. He was extremely ill for 6 months but then gradually improved and developed normally. However, there was an intermittent discharge from sinuses on both sides of the neck, which continued until age 17. He was admitted to hospital in August, 1957, with a 2-year history of epigastric pain, not related to meals but relieved by alkalis.

Examination.-He was fairly healthy looking; there was limitation of neck movements in all directions with healed sinuses on both sides of the neck, right elbow, left forearm, and right cheek. There was shortening of the right ring finger, and the right elbow was ankylosed. The blood pressure was $135 / 100 \mathrm{~mm}$. Hg. There was an otitis media with some discharge. There was no oedema. Proteinuria was present. $X$ rays showed complete fusion of all cervical vertebrae from below the axis. A barium meal showed a traction diverticulum at the level of the tracheal bifurcation and the presence of a duodenal ulcer. Renal biopsy was performed at this time.

No follow-up was possible as contact with the patient was lost.

Case 3, a female aged 37.-In 1932 (at age 12) the patient was treated for osteomyelitis of the sacrum and was in hospital for 2 years. In addition there was an intermittent discharge of pus from the rectum.

1941: In hospital with presacral abscess.

1942: Osteomyelitis of sacro-iliac joints.

1943: Normal pregnancy. No proteinuria.

1947: Normal pregnancy, except for transient urinary infection. Blood pressure $120 / 80 \mathrm{~mm}$. Hg.

1957 June: Febrile episode with pus discharging from the rectum.

September: Urine stated to be free from protein.

October: Admitted to hospital with anaemia and renal failure at which time proteinuria was found and renal biopsy performed.

Examination.-The patient was pale and thin; the blood pressure was $150 / 80 \mathrm{~mm}$. Hg. There was no oedema. There was a well-healed scar over the right sacro-iliac joint. Sigmoidoscopy showed no significant abnormality.

1959 June: She was re-admitted to hospital because of persistent vomiting and headaches; the blood pressure $230 / 130 \mathrm{~mm}$. $\mathrm{Hg}$, and haemorrhages and exudates were present in the fundi. She developed a cerebral haemorrhage and died shortly afterwards.

Case 4, a male aged 30.- In August, 1945 (at age 17) pulmonary tuberculosis was diagnosed and he was treated with rest in bed.

1951 March to October: He was treated with P.A.S.
1954 February: He started treatment with streptomycin and isoniazid.

December: Left thoracoplasty was performed, and proteinuria was noticed post-operatively.

1955 July: He had a further operation after which proteinuria increased. The blood pressure at this time was said to be slightly raised.

1957 March: The blood pressure was $135 / 80 \mathrm{~mm} . \mathrm{Hg}$; there was no proteinuria.

December: He was referred to another hospital because of proteinuria. At this time the blood pressure was $150 / 100 \mathrm{~mm}$. $\mathrm{Hg}$; there was slight ankle oedema and old thoracoplasty. There had never been any micturition symptoms, nor any nocturia. There had been no discharge at any time from the operation site.

1958 January: He was admitted to hospital.

Examination.-He was a rather thin but healthylooking man. There was no oedema and no clubbing. The venous pressure not raised. The blood pressure was $180 / 96 \mathrm{~mm}$. $\mathrm{Hg}$. The urine contained large quantities of protein with a few white cells and epithelial cells in the sediment.

Since the renal biopsy (February, 1958) he has remained fully active; there has been no deterioration in renal function up to July, 1959, although proteinuria still persists.

Case 5, a female aged 46.-In 1942 (at age 30) the patient started having joint pains, affecting the shoulders, wrists, hands, and knees. She received physiotherapy with only slight improvement. In 1954 the symptoms became considerably worse and she presented the typical appearances of rheumatoid arthritis. For the following year she had monthly injections of bismuth but the arthritis continued to progress. In January, 1958, she developed an erythematous rash on the face. No L.E. cells were found in the peripheral blood and the urine was said to be normal. She was started on chloroquine therapy, which was continued until October, 1958. In September, 1958, proteinuria was found for the first time.

Examination (November, 1958).-She was small and wasted with gross limitation of many joints and typical rheumatoid appearance of the hands. The blood pressure was $130 / 80 \mathrm{~mm}$. Hg. There were no abnormal physical signs in any other system.

Following renal biopsy in November, 1958, she has shown some deterioration in her general condition, although there is some diminution in proteinuria.

Case 6, a male aged 60.- In November, 1958, he developed bronchopneumonia which was treated with penicillin and tetracycline. A heavy proteinuria was found and because of this he was admitted to hospital. In 1953 he had been in another hospital with a chest infection and proteinuria had been noted at that time; there had been no urine examination between that time and the recent illness. At no time had there been any 
history of swelling of the legs or any other part of the body. In 1917 (at age 17) he had sustained a gunshot wound of the left knee with local bone infection; arthrodesis of the knee was performed and he was discharged after 9 months. There has been no trouble with the knee since that time.

Examination.- He was healthy looking. There was an old arthrodesis of left knee with healthy scars above the knee joint, and no evidence of a discharging sinus. The blood pressure was $120 / 80 \mathrm{~mm}$. Hg. There was no oedema. $X$-rays showed arthrodesis of the left hip and distortion of the lower femur, but no evidence of sequestra. There was no pulmonary lesion.

Since the stay in hospital from November, 1958, to January, 1959, when renal biopsy was performed, there have been several episodes of oedema, but when he was last seen in October, 1959, he was well and showed no oedema. There has been no rise in blood pressure but proteinuria persists unaltered.

Case 7, a male aged 38.- - In 1931 (at age 10) he had osteomyelitis of the right hip, which was drained surgically; the acute lesion subsided and a bony ankylosis of the hip joint occurred. There had been no further evidence of any active bone lesion at any time, but although the joint was mobile, the position was bad and in August, 1955, a subtrochanteric osteotomy was performed. Since that time mobility has been excellent and he has been able to run and ride a bicycle. Ever since discharge from hospital at the age of 13 , following the episode of osteomyelitis, there have been periodic episodes of asthma. In 1949 he had a severe attack of persistent diarrhoea and ulcerative colitis was diagnosed. He remained in hospital for 3 months and made a good recovery. In 1951 there was a further attack of ulcerative colitis which again cleared up with rest in bed. In October, 1957, there was a further severe recurrence of ulcerative colitis and he was treated for 3 months with cortisone, at first $150 \mathrm{mg}$. and subsequently $100 \mathrm{mg}$. daily. While taking cortisone he suddenly developed gross oedema which was affected neither by stopping the cortisone, nor by mercurial diuretics. There is no record of any urine test at that time. In August, 1958, there was an attack of right lower lobe pneumonia, which resolved rather slowly. In October, 1958, he had herpes zoster in the right second lumbar region and he was admitted to hospital on December 3, 1958, with fever and evidence of a right lower lobe pneumonia.

Examination.-He was a rather small pale man, febrile, with tachycardia and dyspnoea, and moderate oedema up to the knees. The blood pressure was $130 / 80 \mathrm{~mm}$. $\mathrm{Hg}$. There were crepitations and poor air entry at the right base. The right hip was ankylosed, but painless, with no evidence of any discharging sinus. Heavy proteinuria was present.

Following renal biopsy on February 4, 1959, he has kept very well and has been doing full work. The blood pressure has not risen, the plasma protein pattern has improved, and proteinuria has diminished from approximately $1 \mathrm{~g} . / 100 \mathrm{ml}$. in January, 1959 , to $200 \mathrm{mg} . / 100 \mathrm{ml}$. in November, 1959. At this time the maximum urinary specific gravity was 1,030 and the blood urea $40 \mathrm{mg}$./ $100 \mathrm{ml}$.

Case 8, a male aged 59.- - He had an attack of pneumonia as a child and had always been liable to coughs and colds and general ill-health since that time. During the 1914-1918 war he was gassed; this was not followed by any marked deterioration in health. In 1942 he had an attack of pneumonia and ever since this time had had recurrent episodes of chest infection, and moderate amounts of yellowish sputum almost continuously. Examination and culture of sputum have been repeatedly negative, and there was no history of any pleural involvement. He was admitted to hospital in April, 1959, with an exacerbation of his chronic symptoms.

Examination.-He was fairly well-looking, and not cyanosed. There was clubbing of fingers and toes, but no oedema. The blood pressure $100 / 65 \mathrm{~mm}$. Hg. There was markedly diminished movement of the left chest, and generalized rales over the left lung. $X$-ray of the chest showed diffuse cystic bronchiectasis. The urine contained large amounts of protein varying from 5 to $14 \mathrm{~g}$. per 24 hrs. Proteinuria had been discovered in January, 1959.

No follow-up has been possible since the renal biopsy on April 17, 1959.

Case 9, a male aged 54.-For 20 years the patient had had repeated episodes of vague abdominal discomfort, lasting about 10 days and recurring 2 or 3 times a year. The episodes were not usually associated with vomiting, diarrhoea, or constipation, nor with any severe pain. He was admitted to hospital on May 19, 1959, following a similar episode, in which abdominal pain was associated with vomiting and diarrhoea. This attack passed off after 3 days. Never at any time had he complained of any micturition symptoms. Apart from some tightness of his shoes during the last 6 months, there had been no other significant symptoms.

Examination.-He was an alert and healthy-looking man. There was slight oedema of the ankles, the venous pressure was not raised, and the blood pressure 160/110 $\mathrm{mm}$. Hg. There were no other abnormal physical signs. The urine contained considerable quantities of protein.

Following renal biopsy in May, 1959, he has remained fairly well. Some oedema of the legs has been present and proteinuria persists.

Case 10, a male aged 35.-In 1946 (at age 22) pulmonary tuberculosis was diagnosed and a pneumoperitoneum was maintained for 18 months. In 1949, bilateral orchidectomy for genital tuberculosis was performed and a two-stage thoracoplasty carried out. He remained well until June, 1956, when proteinuria was discovered, but renal function was normal and a 
Congo red uptake test and a gum biopsy failed to confirm a diagnosis of amyloidosis. By November, 1957, the proteinuria had increased markedly but no oedema was present. At this time amyloid was diagnosed by liver biopsy.

In August, 1959, he was admitted to hospital again with upper abdominal pain and nausea. The blood pressure had risen to $180 / 120 \mathrm{~mm}$. $\mathrm{Hg}$ and oedema was present. There was no evidence of an active tuberculous lesion and the blood urea was only slightly higher than 2 years before.

A renal biopsy was performed on August 8th, 1959, to exclude a renal lesion other than amyloid.

Case 11, a female aged 26. - In 1936 (at age 3) bronchiectasis was discovered following a severe attack of measles.

1948 September: A bilateral Caldwell-Luc operation was performed.

October: A right middle and lower lobectomy was performed.

1949 Octoher: The left lower lobe and lingula were removed.

1953: Both tonsils were removed.

1956 August: She had a normal full-term delivery.

1958 August: She had an appendicectomy, and the urine at this time was free of protein.

September: Proteinuria was discovered during a pregnancy and this persisted after a normal full-term delivery in February, 1959.

Since 1950 she has had intermittent chest infections controlled by tetracycline, but she produces moderate amounts of greenish sputum even during remission.

1959 June: She was admitted to hospital for investigation of proteinuria.

Examination.-She appeared healthy; there was no oedema and the blood pressure was $140 / 75 \mathrm{~mm}$. $\mathrm{Hg}$. The liver was felt two finger-breadths below the costal margin. The urine contained up to $5 \cdot 3 \mathrm{~g}$. protein per 24 hrs. Suspecting amyloidosis, a liver biopsy and gum biopsy were performed, neither of which showed amyloid. The renal biopsy performed 4 months later, however, showed amyloid.

\section{Pathological Findings}

Renal biopsy was performed and sections prepared as described in a previous publication (Joekes, Heptinstall, and Porter, 1958). Table II shows the distribution and extent of the amyloid infiltration in the eleven biopsies. Methyl violet was used as a stain for amyloid. The main distribution is in the capillary tufts of the glomeruli and was present in

TABLE II

ANALYSIS OF PATHOLOGICAL FINDINGS

\begin{tabular}{|c|c|c|c|c|c|}
\hline $\begin{array}{l}\text { Case } \\
\text { No. }\end{array}$ & $\begin{array}{l}\text { No. of } \\
\text { Glomeruli }\end{array}$ & $\begin{array}{l}\text { Glomerular Involve- } \\
\text { ment by Amyloid }\end{array}$ & $\begin{array}{l}\text { Amyloid in Vessels } \\
(0 \text { to }++)\end{array}$ & $\begin{array}{l}\text { Tubular } \\
\text { Loss }\end{array}$ & $\begin{array}{c}\text { Amyloid in Medulla } \\
(0 \text { to }+) \\
(- \text { signifies no medulla } \\
\text { in specimen })\end{array}$ \\
\hline 1 & 18 & $\begin{array}{l}\text { 9/10 Atr. } \\
\text { 1/10 Mod. }\end{array}$ & + & Severe & - \\
\hline 2 & 14 & $\begin{array}{l}\text { 1/3 Atr. } \\
\text { 2/3 Min. or Normal }\end{array}$ & + & Slight & - \\
\hline 3 & 20 & $\begin{array}{l}\text { 2/3 Mod. } \\
\text { 1/3 Min. }\end{array}$ & ++ & Severe & - \\
\hline 4 & 35 & $\begin{array}{l}\text { 1/3 Atr. } \\
\text { 2/3 Mod. }\end{array}$ & + & Slight & - \\
\hline 5 & 20 & $\begin{array}{l}\text { 1/2 Min. } \\
1 / 2 \text { Normal }\end{array}$ & ++ & None & $+\div$ \\
\hline 6 & 28 & $\begin{array}{l}\text { 1/10 Atr. } \\
\text { 9/10 Min. }\end{array}$ & + & Slight & $\div$ \\
\hline 7 & 64 & $\begin{array}{l}\text { 9/10 Atr. } \\
\text { 1/10 Mod. }\end{array}$ & $\div$ & Very severe & $T$ \\
\hline 8 & 12 & 10/10 Mod. & $T$ & Slight & $\div$ \\
\hline 9 & 50 & $\begin{array}{l}\text { 1/2 Sev. } \\
\text { 1/2 Mod. }\end{array}$ & \pm & Moderate & - \\
\hline 10 & 28 & $\begin{array}{l}\text { 1/10 Sev. } \\
\text { 9/10 Mod. }\end{array}$ & + & Slight & + \\
\hline 11 & 25 & $\begin{array}{l}\text { 3/10 Atr. } \\
\text { 7/10 Mod. }\end{array}$ & + & Slight & + \\
\hline
\end{tabular}

Abbreviations in Col. 3: Atr.-small tufts with only faint staining for amyloid and often with surrounding rim of collagen. Min.- minor changes-small local thickenings of capillaries in tuft.

Mod.-moderate changes-more extensive nodular thickenings of capillaries in tuft. Sev.-severe changes-considerable amyloid replacement of walls of tuft capillaries. 
this site in every case, involving every glomerulus in the specimen in nine out of the eleven biopsies. The earliest change consisted of small thickenings of the capillary basement membrane, sometimes affecting many. At a later stage the thickenings were larger and more nodular, the nodules having a "soft" diffuse eosinophilic appearance (Fig. 1). In some cases the nodules were more compact and bore a great resemblance to the nodules seen in diabetic glomerulo-sclerosis but differing in that they gave a strongly positive reaction for amyloid. A more advanced form of change consisted of small reduced tufts with few nuclei and showing either ghosts of basement membranes which stained for amyloid in a rather patchy way or small clumps of amyloid. This weakening and disappearance of staining reactions for amyloid in severely affected glomeruli has been noted by Fahr (1925) and Noble and Major (1929). These atrophic tufts frequently showed a surrounding mantle of collagen (Fig. 2). One case showed a pronounced diffuse amyloid thickening of

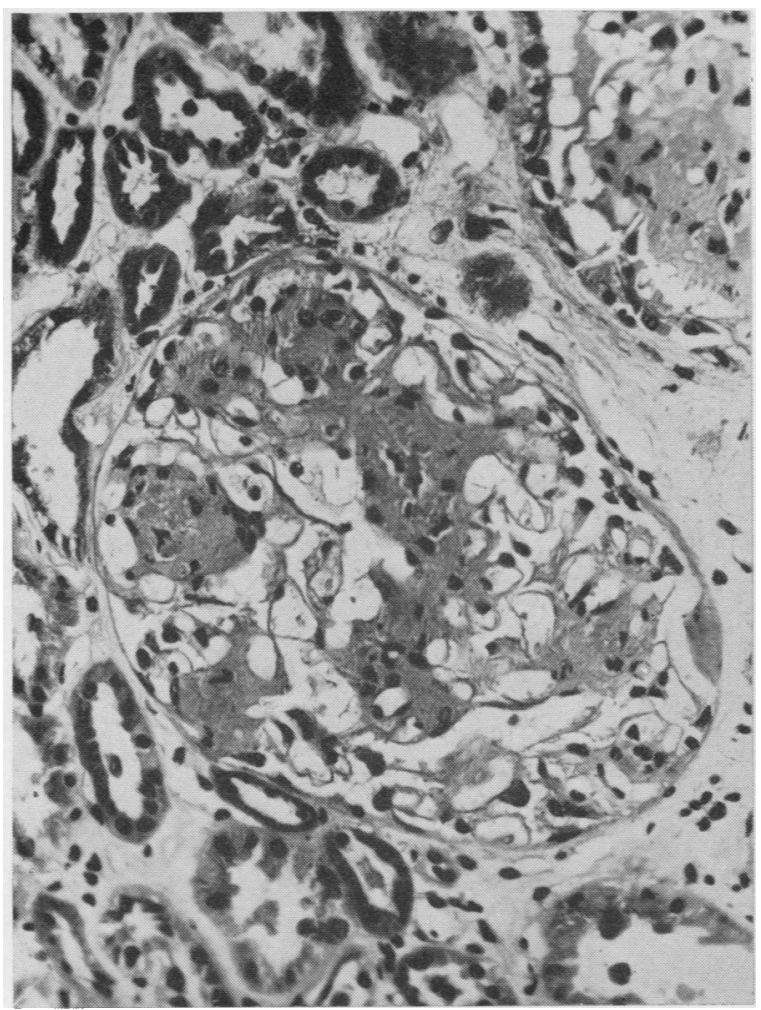

Fig. 1.-Case 6, glomerulus showing early to moderate amyloid change. This takes the form of small "soft" eosinophilic nodules occurring in relation to capillary basement membranes. Haematoxylin and eosin $\times 240$. the capillary basement membranes, which in places was so extreme as to obliterate the capillaries (Fig. 3, overleaf). The glomeruli in this case showed large amounts of stainable lipid in areas which also stained for amyloid.

Tubular changes were surprisingly slight compared with the glomerular damage. In only three cases was there severe tubular loss and in one of these practically all tubules had disappeared (Fig. 4, overleaf). In biopsies with less severe tubular loss there was either atrophy or disappearance of proximal convoluted tubules related to severely involved glomeruli. Atrophic tubules lined by a flattened type of epithelium and containing rounded eosinophilic casts were frequently found and when these were numerous the appearance was reminiscent of the changes seen in chronic pyelonephritis. In two cases in which frozen sections were prepared, lipid was present in proximal convoluted tubules. The casts gave negative staining reactions for amyloid.

The arterioles and small arteries of all cases showed thickening in which amyloid could be

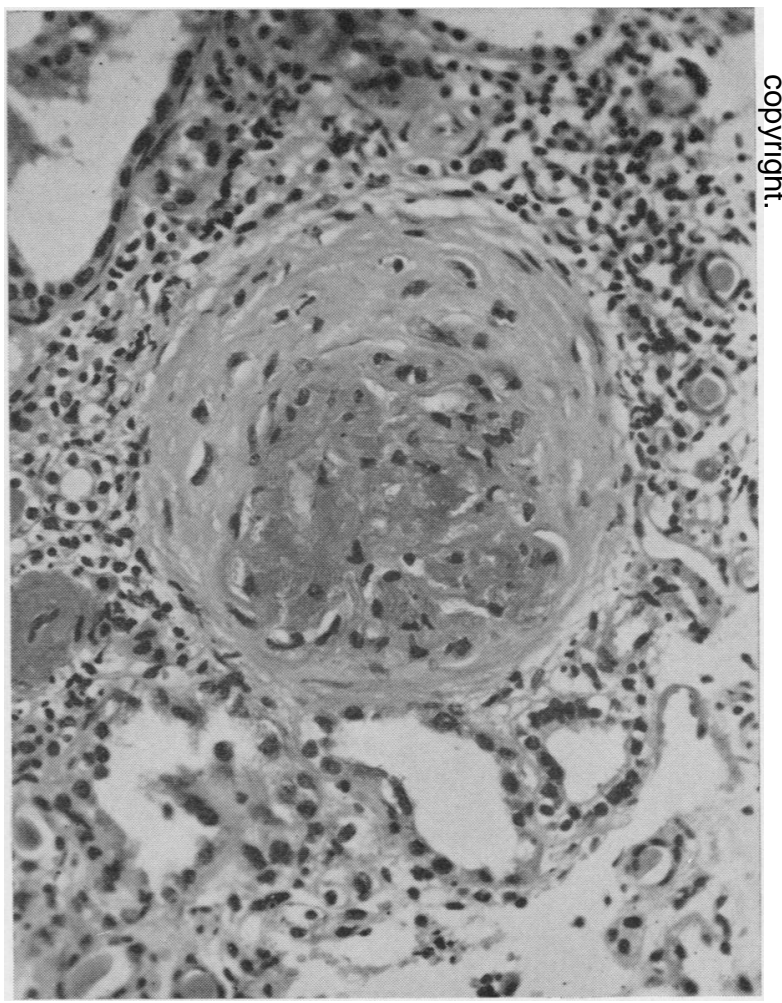

Fig. 2.-Case 4, atrophic glomerulus showing tuft to be structureless and replaced by amyloid with surrounding mantle of collagen.

Haematoxylin and eosin $\times 240$. 


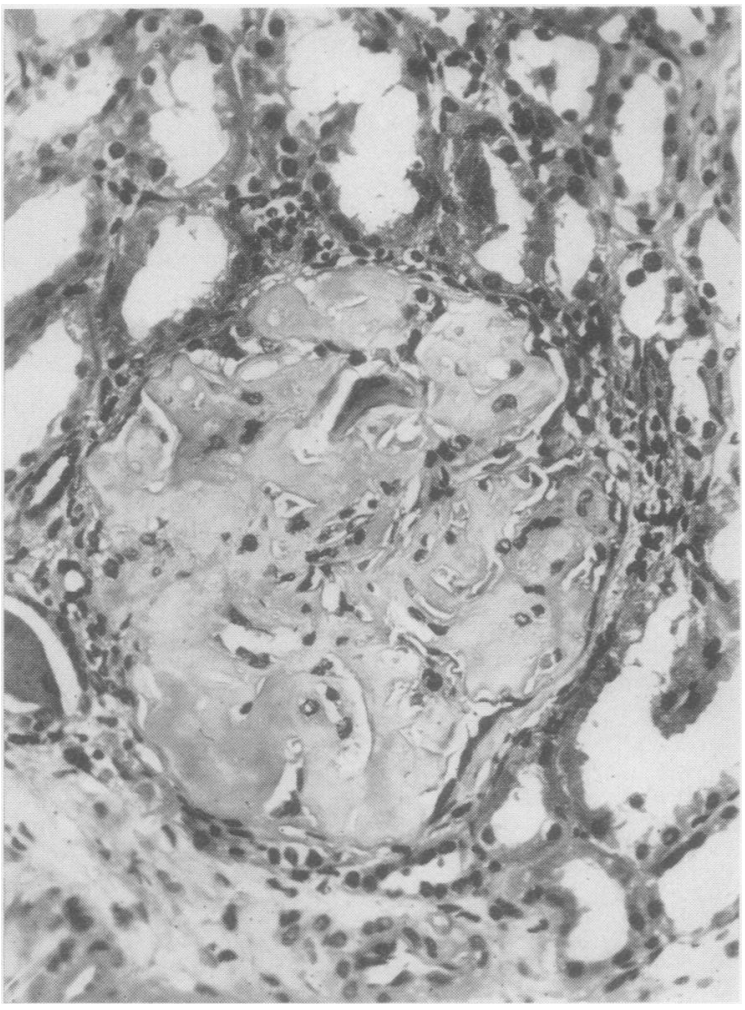

Fig. 3.-Case 9, severe glomerular change in which amyloid is almost completely obliterating the capillaries of the tuft. Haematoxylin and eosin $\times 240$.

demonstrated. In the least severely involved vessels the amyloid was deposited in the media and adventitial coats. There was no correlation between the amount of amyloid in arteries and the amount in glomeruli. It was slight in the vessels in two cases with extensive glomerular change, and of the two cases with the greatest amount of arterial amyloid one was that with the least severe glomerular change of the whole series. Intimal arterial thickening of either elastic or fibrous type was common.

The interstitial tissue showed increased fibrosis in cases with the most extreme tubular loss, and lymphocytes were often found. In six cases in which the biopsy included medulla, there was amyloid deposition in and around capillary walls and to a lesser extent in tubular basement membranes. The case with the most extensive amyloid in the medulla was one of the two with the most severe vascular amyloid and the one with the least glomerular amyloid of the series.

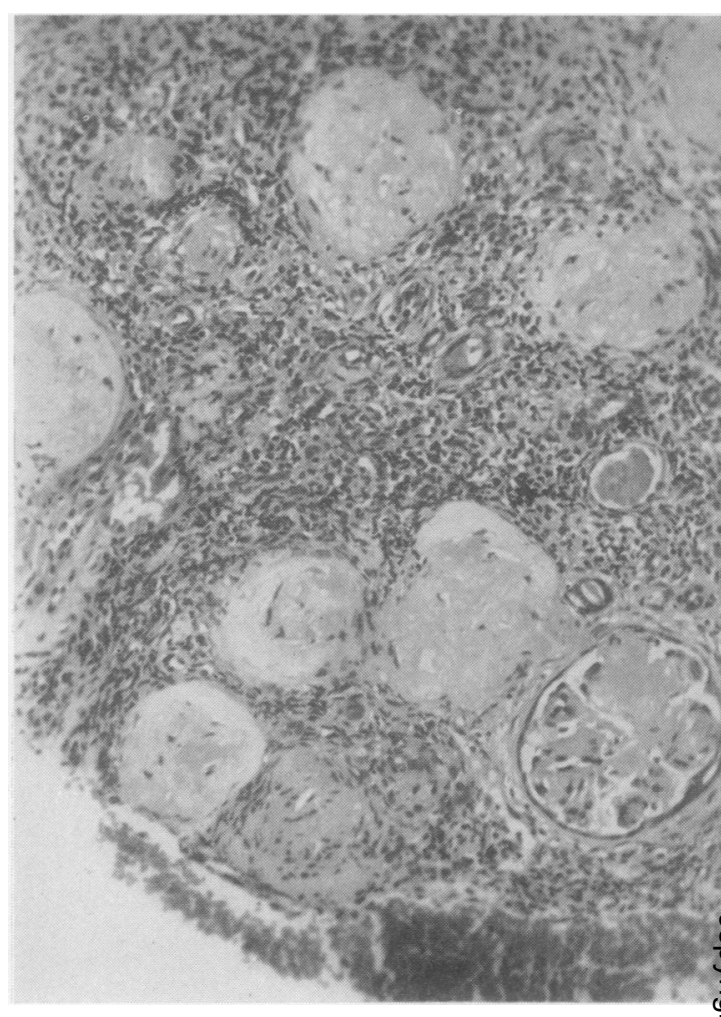

Fig. 4.-Case 7, considerable tubular loss in relation to atrophic glomeruli. Lymphocytes are profuse in the interstitium. Haematoxylin and eosin $\times 140$.

\section{Discussion}

The pathological changes conform to previous descriptions (Bell, 1933), and very little can be added. It is of interest, however, that Case 9 showed extensive deposits of lipid stainable with Oil Red $\mathrm{O}$ in those parts of the glomeruli which contained amyloid. Most descriptions of the staining properties of amyloid indicate that there is no lipid content (Wagner, 1957; Braunstein and Buerger, 1959), and although Symmers (1956) referred to abundant finely dispersed sudanophil lipid occurring in some amyloid deposits, the amount in the present case was striking. This particular case was one in which there was no antecedent history of any of the diseases usually associated with amyloid.

Several points of interest were noted in these patients. Hypertension was seen more commonly than has been described in previous series of patients with renal amyloid involvement. Rosenblatt (1933), in 87 cases, never found the systolic blood pressure 
over $140 \mathrm{~mm} . \mathrm{Hg}$, and Dixon (1934) found systolic blood pressure over $150 \mathrm{~mm}$. $\mathrm{Hg}$ in only four out of 35 cases. In patients with renal failure and amyloid infiltration, Mark and Mosenthal (1938) found a raised blood pressure in only three out of twenty cases. Before the use of specific therapy for infections such as tuberculosis and osteomyelitis, the presence of amyloid infiltration is likely to have occurred with persistent infection. The metabolic complications of long-standing infection may prevent the development or maintenance of hypertension, and it is possible that the patients in the present series showed a greater incidence of hypertension which was due to their relatively good general condition.

Amyloid renal involvement is always listed as a cause of the nephrotic syndrome. At the time of renal biopsy all the patients had proteinuria, in some exceeding a loss of $10 \mathrm{~g}$. per 24 hrs. Nevertheless, only four patients had oedema at any time, and in only two was this more than slight. The plasma albumin concentration was not markedly reduced except in Cases 6 and 7, nor was the plasma cholesterol usually raised, exceeding $300 \mathrm{mg}$./100 ml. in only one patient. In two patients (Cases 1 and 4) proteinuria had been known to be present for 8 and 3 years respectively and yet no oedema had been present.

In one patient (Case 9) there was no history or evidence of any underlying disease and a presumptive diagnosis of primary amyloidosis was made. In the other ten cases there was a history of osteomyelitis in five, of pulmonary tuberculosis in two, of chronic purulent bronchiectasis in two, and of rheumatoid arthritis in one. The association of amyloid infiltration with these conditions has been well documented in the past and is not reviewed here. In both patients with bronchiectasis (Cases 8 and 11), recurrent infection persisted, and in Case 5 the rheumatoid arthritis was active and progressive. In Case 4 there had been no evidence of active tuberculosis for 3 years, and in Case 10 for 10 years; it is, however, not possible to exclude the presence of small caseating foci. In Case 3 active osteomyelitis had been present up to a few months before renal amyloidosis was shown by biopsy. In the other four cases with a past history of osteomyelitis the interval between the last evidence of activity and the proof of the presence of renal amyloidosis by biopsy ranged from 8 to 40 years. In Case 7, however, there was a history of ulcerative colitis during a period of 2 years up to one year before the renal biopsy, and this may have resulted in the renal amyloid infiltration, although evidence from the literature for amyloidosis complicating ulcerative colitis is very sparse. In Case 6 there was no evidence of any infection or necrosis in the wounded knee for 40 years, nor had there been any major illness during this time. Although this patient had been admitted to hospital for minor illnesses on several occasions, proteinuria was not found until some months before the renal biopsy. It is impossible to say whether the old knee wound and the amyloid deposition are causally linked, but long intervals of apparent inactivity of the bone lesion before the finding of renal amyloid are present in other cases. In view of this and of the well-known association between osteomyelitis and amyloidosis, it is difficult to discount the old injury as the cause for the amyloidosis in Case 6. Brouet, Chrétien, and Legrain (1958) described two post mortem cases of pulmonary tuberculosis with renal amyloid infiltration in which proteinuria was absent in life, and another similar patient in whom proteinuria was only intermittently present. The apparent absence of proteinuria for long periods after any activity in an underlying lesion in the patients in the present series cannot be taken as evidence against renal amyloid infiltration. It may be possible that once amyloid deposition has started in the kidneys there may be progression, although there is no longer any active underlying lesion. The rate of progression must, however, be slow in these patients and of quite a different order from that in the patient described by Muehrcke, Pirani, Pollak, and Kark (1955), in whom the degree of amyloid infiltration, as judged by repeated renal biopsies, progressed markedly in the space of one year and the urea clearance fell from $46 \mathrm{ml} . / \mathrm{min}$. to $2 \mathrm{ml} . / \mathrm{min}$.

The most surprising finding in these patients is the good renal function in view of the severe infiltration with amyloid. Histologically extensive glomerular infiltration by amyloid sometimes occurred without any gross abnormalities in the tubules, but in other cases tubular damage was severe (Cases 1, 3, and 7). The dissociation between structural changes and renal function was not confined to those cases with slight tubular involvement. This is most strikingly illustrated by Case 7 , in which there were very gross histological changes and yet very good renal function with creatinine clearance repeated on two occasions of the order of $92 \mathrm{ml} . / \mathrm{min}$., and a maximum urinary concentration as judged by specific gravity of 1,030 . This raises the question of the validity of renal biopsy in reflecting the overall renal changes. Previous descriptions of the distribution of amyloid in the kidney and our own examination of kidneys obtained at autopsy, indicate that the glomerular involvement is diffuse, and it is hard to conceive 
that the biopsies reported in this series fail to reflect the true state of affairs in the kidney. In Case 7, in order to minimize the chances of an unrepresentative piece of material, three separate pieces were obtained from the same kidney at the same time. There was no significant difference in the degree of involvement in the three specimens. However, Brouet and others (1958) have described one case where severe involvement with amyloid was found at post mortem in one kidney, while the other was normal; pulmonary tuberculosis was present and was accepted as the underlying cause for the amyloidosis. Apart from this case which is difficult to understand we have found no record of localized renal amyloid. The explanation for this divergence between structure and function is unexplained.

In three patients, Cases 7, 10, and 11, a gum biopsy for amyloid was negative, as was the Congo red test in Cases 2, 7, 8, and 10, and in Case 11 a liver biopsy was negative 3 months before the positive renal biopsy at a time when proteinuria was already present. If evidence of renal involvement is present and the possibility of secondary amyloidosis is considered, a renal biopsy would seem to be both the most direct and certain method of making a diagnosis.

\section{Summary}

(1) Eleven cases of amyloid disease of the kidney have been encountered in 220 successful percutaneous needle biopsies of the kidney.

(2) In ten cases there was antecedent disease: osteomyelitis in five, pulmonary tuberculosis in two, chronic purulent bronchiectasis in two, and rheumatoid arthritis in one.

(3) A diastolic blood pressure over $100 \mathrm{~mm}$. $\mathrm{Hg}$ was found in six cases.

(4) It was striking that the tendency to develop a full nephrotic syndrome was uncommon even with prolonged proteinuria.

(5) A feature of the series was the dissociation between structural change and renal function.

\section{REFERENCES}

Bell, E. T. (1933). Amer. J. Path., 9, 185.

Braunstein, H., and Buerger, L. (1959). Ibid., 35, 791

Brouet, G., Chrétien, J., and Legrain, M. (1958). J. Urol. méd. chir., 64, 557.

Dixon, H. M. (1934). Amer. J. med. Sci., 187, 401.

Fahr, T. (1925). In "Handbuch der speziellen pathologischen Anatomie und Histologie", ed. F. Henke and O. Lubarsch, band 6 , teil 1, p. 242. Springer, Berlin.

Fearnley, G. R., and Lackner, R. (1955). Brit. med. J., 1, 1129.

Fingerman, D. L., and Andrus, F. C. (1943). Ann. rheum. Dis., 3, 168 .

Joekes, A. M., Heptinstall, R. H., and Porter, K. A. (1958). Quart. J. Med., N.S. 27, 495.

Mark, M. F., and Mosenthal, H. O. (1938). Amer. J. med. Sci., 196, 529 .

Muehrcke, R. C., Pirani, C. L., Pollak, V. E., and Kark, R. M. (1955). Guy's Hosp. Rep., 104, 295

Noble, J. F., and Major, S. G. (1929). Arch. Path. (Chicago), 8, 762.

Rosenblatt, M. B. (1933). Amer. J. med. Sci., 186, 558.

Symmers, W. St. C. (1956). J. clin. Path., 9, 187.

Teilum, G., and Lindahl, A. (1954). Acta med. scand., 149, 449.

Wagner, B. M. (1957). In "Analytical Pathology", ed. R. C. Mellors p. 461. McGraw-Hill, New York.

\section{Amyloïdose rénale \\ RÉSUMÉ}

(1) Au cours de 220 ponctions efficaces du rein, on a trouvé onze cas d'amyloïdose rénale.

(2) Dans dix des cas, il y avait eu une maladie antécédente: ostéomyelite dans 5 cas, tuberculose pulmonaire dans deux, bronchiectasie purulente chronique dans deux, et arthrite rhumatismale dans un.

(3) On a trouvé une tension artérielle minima de $100 \mathrm{~mm}$. de $\mathrm{Hg}$ dans six cas.

(4) On a été frappé par le fait que la tendance à développer un syndrome néphrotique classique était rare même dans les cas d'albuminurie prolongée.

(5) Un des traits remarquables de la série était dissociation entre les altérations structurales et fonction rénale.

\section{Amiloidosis renal}

SUMARIO

(1) Entre 220 punciones biópsicas de riñon llevados a cabo con éxito, se encontraron 11 casos de amiloidosis renal.

(2) En diez de estos casos existía enfermedad previa: osteomielitis en cinco, tuberculosis pulmonar en dos, bronquiectasis con infección purulenta crónica en dos y artritis reumatoide en uno.

(3) En seis enfermos la presión vascular diastólica era de $100 \mathrm{~mm}$. de $\mathrm{Hg}$.

(4) Llamó la atención el hecho de la escasa tendencia que presentan estos enfermos a desarrollar un síndrome nefrótico clásico, aún en casos con prolongada proteinuria.

(5) Resulta remarcable la disociación encontrada entre los cambios estructurales y la función renal. 